\title{
Kineococcus vitellinus sp. nov., Kineococcus indalonis sp. nov. and Kineococcus siccus sp. nov., Isolated Nearby the Tabernas Desert (Almería, Spain)
}

\author{
Esther Molina-Menor ${ }^{1}$, Helena Gimeno-Valero ${ }^{2}$, Javier Pascual ${ }^{2}\left(0\right.$, Juli Peretó ${ }^{1,2,3}{ }^{\circledR}$ and \\ Manuel Porcar ${ }^{1,2, *}$ \\ 1 Institute for Integrative Systems Biology I2SysBio (Universitat de València-CSIC), Calle del Catedràtic \\ Agustin Escardino Benlloch 9, 46980 Paterna, Spain; esther.molina@uv.es (E.M.-M.); juli.pereto@uv.es (J.P.) \\ 2 Darwin Bioprospecting Excellence SL. Parc Científic Universitat de València, Calle del Catedràtic Agustin \\ Escardino Benlloch 9, 46980 Paterna, Spain; hgimeno@darwinbioprospecting.com (H.G.-V.); \\ jpascual@darwinbioprospecting.com (J.P.) \\ 3 Departament de Bioquimica i Biologia Molecular, Universitat de València, Calle del Dr. Moliner 50, \\ 46100 Burjassot, Spain \\ * Correspondence: manuel.porcar@uv.es
}

Received: 31 August 2020; Accepted: 2 October 2020; Published: 7 October 2020

\begin{abstract}
Three novel Gram-positive, aerobic, chemoheterotrophic, motile, non-endospore-forming, orange-pigmented bacteria designated strains $\mathrm{T} 13^{\mathrm{T}}, \mathrm{T} 90^{\mathrm{T}}$ and $\mathrm{R} 8^{\mathrm{T}}$ were isolated from the Tabernas Desert biocrust (Almería, Spain). Cells of the three strains were coccus-shaped and occurred singly, in pairs or clusters. The three strains were oxidase-negative and catalase-positive, and showed a mesophilic, neutrophilic and non-halophilic metabolism. Based on the 16S rRNA gene sequences, the closest neighbours of strains $\mathrm{T} 13^{\mathrm{T}}, \mathrm{T} 90^{\mathrm{T}}$ and $\mathrm{R} 8^{\mathrm{T}}$ were Kineococcus aurantiacus $\mathrm{IFO} 15268^{\mathrm{T}}$, Kineococcus gypseus YIM $121300^{\mathrm{T}}$ and Kineococcus radiotolerans SRS $30216^{\mathrm{T}}$ (98.5\%, $97.1 \%$ and $97.9 \%$ gene sequence similarity, respectively). The genomes were sequenced, and have been deposited in the GenBank/EMBL/DDBJ databases under the accession numbers JAAALL000000000, JAAALM000000000 and JAAALN000000000, respectively, for strains $\mathrm{T} 13^{\mathrm{T}}, \mathrm{T} 90^{\mathrm{T}}$ and $\mathrm{R} 8^{\mathrm{T}}$. The average nucleotide identity (ANIb) and digital DNA-DNA hybridization (dDDH) values confirmed their adscription to three new species within the genus Kineococcus. The genomic $\mathrm{G}+\mathrm{C}$ content of strains $\mathrm{T} 13^{\mathrm{T}}, \mathrm{T} 90^{\mathrm{T}}$ and $\mathrm{R} 8^{\mathrm{T}}$ ranged from $75.1 \%$ to $76.3 \%$. The predominant fatty acid of all three strains was anteiso- $\mathrm{C}_{15: 0}$. According to a polyphasic study, strains $\mathrm{T} 13^{\mathrm{T}}, \mathrm{T} 90^{\mathrm{T}}$ and $\mathrm{R} 8^{\mathrm{T}}$ are representatives of three new species in the genus Kineococcus, for which names Kineococcus vitellinus sp. nov. (type strain $\mathrm{T} 13^{\mathrm{T}}=$ CECT $9936^{\mathrm{T}}=$ DSM $110024^{\mathrm{T}}$ ), Kineococcus indalonis sp. nov. (type strain $\mathrm{T}^{\mathrm{T}} 0^{\mathrm{T}}=$ CECT $9938^{\mathrm{T}}=$ DSM $\left.110026^{\mathrm{T}}\right)$ and Kineococcus siccus sp. nov. (type strain R8 ${ }^{\mathrm{T}}=$ CECT $\left.9937^{\mathrm{T}}=\mathrm{DSM} 110025^{\mathrm{T}}\right)$ are proposed.
\end{abstract}

Keywords: new taxa; biocrust; Kineococcus indalonis; Kineococcus siccus; Kineococcus vitellinus; Tabernas Desert

\section{Introduction}

The genus Kineococcus, belonging to the family Kineosporiaceae [1], was first proposed by Yokota et al. in 1993 [2]. At the time of writing, the genus Kineococcus is comprised of 11 species with valid published names (http://lpsn.dsmz.de/) which were isolated from soil [2-5], saline environments [6-8], plants $[9,10]$ and radioactive work areas [11]. This genus includes species with the ability to grow in a wide range of temperatures [5] and high salt concentrations $[8,9]$. Their resistance to multiple 
stresses and extreme conditions has also been reported by several authors, with Kineococcus radiotolerans standing out among them because of its high resistance to radiation [11].

The genus Kineococcus unites Gram-stain-positive, aerobic, catalase-positive and oxidase-negative microorganisms. Colonies are cream to orange in colour, and cells are motile and occur singly, in pairs or in clusters. The major cellular fatty acid is $\mathrm{C}_{15: 0}$ anteiso, whereas diphosphatidylglycerol and phosphatidylglycerol are the major polar lipids. The genomic DNA G + C content of the Kineococcus species ranges from $73.9 \%$ to $74.2 \%$ [12].

During a study on the culturable microbial diversity of biocrust in dry environments exposed to high solar radiation, three different strains, $\mathrm{T} 13^{\mathrm{T}}, \mathrm{T} 90^{\mathrm{T}}$ and $\mathrm{R} 8^{\mathrm{T}}$, were isolated. The objective of the study was to characterize in detail the microbial communities from the Tabernas Desert (Almería, Spain), with particular emphasis in the isolation of extremophilic bacteria. The bacterial strains isolated from similar environmental niches, such as solar panels or the intertidal coastal zone, are able to tolerate UV radiation, and could thus be potentially useful in the synthesis of antioxidant compounds $[13,14]$. Among them, pigments such as carotenoids are particularly valuable for the biotechnological and pharmaceutical industries. In this paper, we describe the isolation and polyphasic characterization of these bacteria, and propose them as new species of the genus Kineococcus, for which the names Kineococcus vitellinus sp. nov., Kineococcus indalonis sp. nov. and Kineococcus siccus sp. nov. are proposed.

\section{Materials and Methods}

\subsection{Isolation of Strains and Culture Conditions}

Biocrust samples were collected in the vicinity of the Tabernas Desert (37.002404 N, 2.450655 W) in September 2018. One gram of each biocrust sample was resuspended in one millilitre of phosphate-buffered saline (PBS) pH 7.4. The suspensions were vigorously shaken, spread on $1 \mathrm{X}, 0.1 \mathrm{X}$ and $0.01 \mathrm{X}$ trypticase soy agar (TSA; in g/L: 15 tryptone, $5 \mathrm{NaCl}, 5$ soya peptone), and Reasoner's 2A agar (R2A; in g/L: 1 peptone, 0.5 yeast extract, 0.5 dextrose, 0.5 soluble starch, 0.3 dipotassium phosphate, 0.05 magnesium sulphate heptahydrate, 0.3 sodium pyruvate) media and incubated at $23^{\circ} \mathrm{C}$ for one week. $\mathrm{T} 13^{\mathrm{T}}$ and $\mathrm{T} 90^{\mathrm{T}}$ strains were isolated from $0.1 \mathrm{X}$ and $0.01 \mathrm{X}$ TSA plates, respectively, whereas $\mathrm{R} 8^{\mathrm{T}}$ was isolated from a $0.1 \mathrm{X}$ R2A plate. All three strains were purified and cultivated by re-streaking on fresh media. For cryopreservation at $-80^{\circ} \mathrm{C}$, cell suspensions in trypticase soy broth (TSB) were supplemented with $15 \%(v / v)$ glycerol. To determine the taxonomic status of strains $\mathrm{T}_{13} 3^{\mathrm{T}}$, $\mathrm{T} 90^{\mathrm{T}}$ and $\mathrm{R} 8^{\mathrm{T}}$, six reference type strains were used in this study: Kineococcus radiotolerans DSM $14245^{\mathrm{T}}$, Kineococcus aurantiacus DSM 7487 ${ }^{\mathrm{T}}$, Kineococcus gypseus DSM $27627^{\mathrm{T}}$ and Kineococcus aureolus DSM $102158^{\mathrm{T}}$ from the DSMZ-German Collection of Microorganisms and Cell Cultures (Leibniz Institute, Braunschweig, Germany), and Kineococcus gynurae NBRC $103943^{\mathrm{T}}$ and Kineococcus mangrovi NBRC $110933^{\mathrm{T}}$ from the NITE Biological Resource Center (Tokyo, Japan). The selection of reference strains was based on the comparison of $16 \mathrm{~S}$ rRNA gene sequences of the three isolates against the EzBioCloud database (http://www.ezbiocloud.net/) as detailed below. The comparative analysis conditions were selected according to the available literature on the species within this genus. Unless otherwise specified, all nine strains were grown on TSA media at $30^{\circ} \mathrm{C}$.

\subsection{DNA Extraction and Sequencing}

Extraction of genomic DNA was carried out using the DNeasy PowerSoil kit (QUIAGEN, Hilden, Germany) according to the manufacturer's instructions. A PCR of the whole 16S rRNA gene was performed with universal primers 8F (5'-AGAGTTTGATCCTGGCTCAG-3') [15] and 1492R (5'-GGTTACCTTGTTACGACTT- $\left.3^{\prime}\right)$ [16] $\left(94^{\circ} \mathrm{C}\right.$ for $5 \mathrm{~min}, 24$ cycles of denaturation at $94{ }^{\circ} \mathrm{C}$ for $15 \mathrm{~s}$, annealing at $48^{\circ} \mathrm{C}$ for $15 \mathrm{~s}$ and elongation at $72{ }^{\circ} \mathrm{C}$ for $5 \mathrm{~min}$, and a final elongation step at $72{ }^{\circ} \mathrm{C}$ for $5 \mathrm{~min}$ ). The $16 \mathrm{~S}$ rRNA gene sequence length of the strains $\mathrm{T} 13^{\mathrm{T}}, \mathrm{T} 90^{\mathrm{T}}$ and $\mathrm{R} 8^{\mathrm{T}}$ were $1415 \mathrm{bp}$ (accession number MN069869), 1425 bp (MN069867) and 1404 bp (MN069868), respectively. The draft genome of 
strains $\mathrm{T} 13^{\mathrm{T}}, \mathrm{T} 90^{\mathrm{T}}$ and $\mathrm{R} 8^{\mathrm{T}}$ was sequenced using a MiSeq sequencer (Illumina, San Diego, CA, USA), and the Nextera XT Prep Kit protocol was used for library preparation.

\subsection{Phylogenetic Analysis}

We identified the closest relatives of the three strains $\mathrm{T} 13^{\mathrm{T}}, \mathrm{T} 90^{\mathrm{T}}$ and $\mathrm{R} 8^{\mathrm{T}}$ by comparing their $16 \mathrm{~S}$ rRNA gene sequences against the EzBioCloud database update 2020.05.13 (http://www.ezbiocloud.net/). Maximum-likelihood (ML) (Figure 1) [17] and neighbour-joining trees (NJ) (Figure 2) [18] were inferred with the software MEGA Xv.10.1.7 (https://www.megasoftware.net/). The Tamura-Nei G+I evolutionary model was used for the ML tree, whereas the Kimura two-parameter model was used for the NJ tree. The reliability of the branch patterns was assessed using bootstrap analysis based on 500 replicates for the ML tree and on 1000 replicates for the NJ tree [19]. Acidimicrobium ferrooxidans DSM $10331^{\mathrm{T}}$ was used as an outgroup for the phylogenetic analyses.

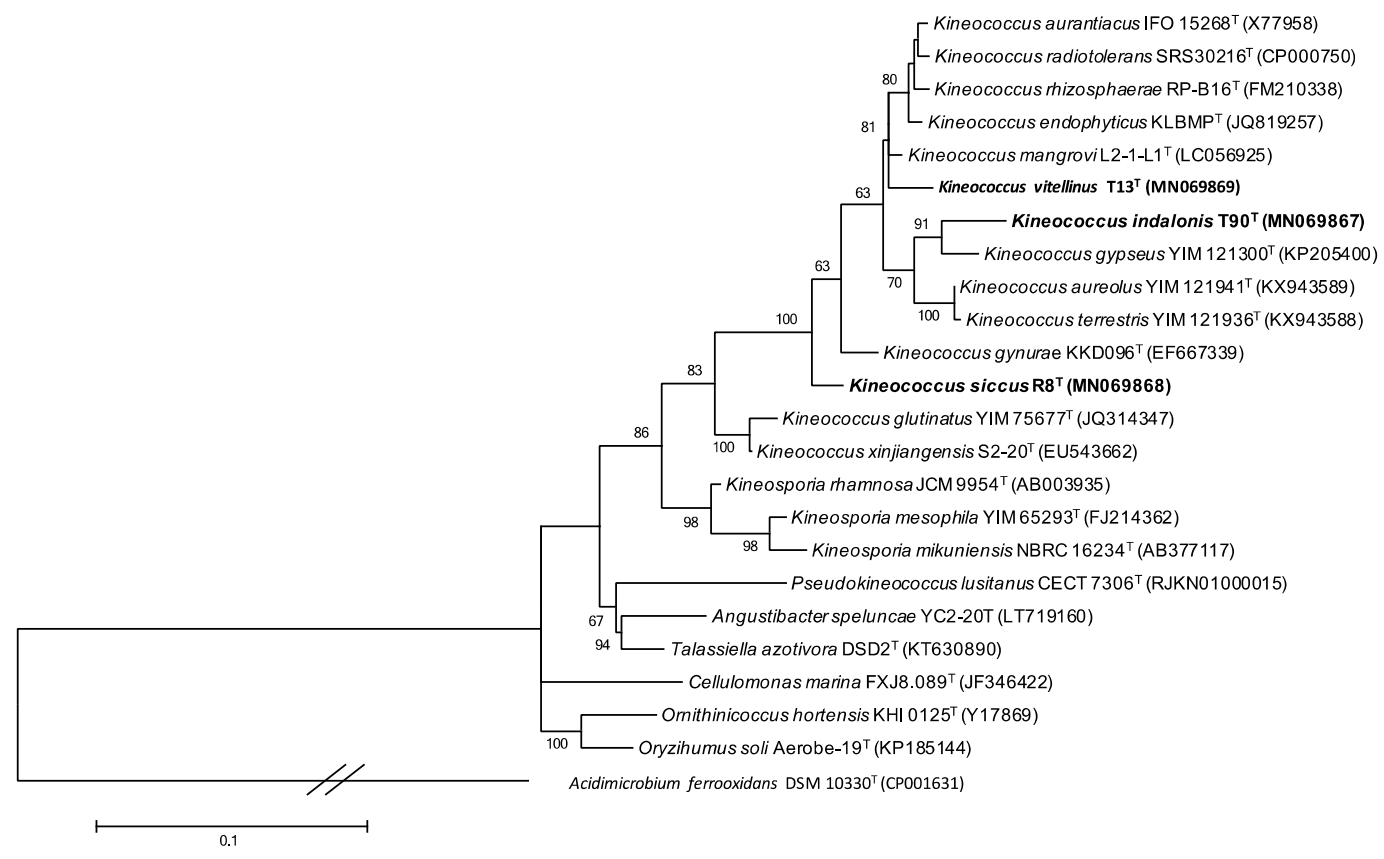

Figure 1. Maximum likelihood phylogenetic tree showing the relationships between strains $\mathrm{T} 13^{\mathrm{T}}, \mathrm{T} 90^{\mathrm{T}}$, $\mathrm{R} 8^{\mathrm{T}}$ and other members of the family Kineosporiaceae based on 16S rRNA sequences. The optimal evolutionary model of nucleotide substitution applied was Tamura-Nei G+I. Numbers at branch points refer to bootstrap percentages based on 500 replicates (values under $50 \%$ are not indicated). Acidimicrobium ferrooxidans DSM $10331^{\mathrm{T}}$ (CP001631) was used as an outgroup. Bar 0.1 fixed nucleotide substitutions per site.

\subsection{Genomic Analysis}

The FastQC tool [20] was used to assess the quality of the sequence reads. Genome assembly of paired reads was performed using SPAdes 3.12.0 [21]. The draft genomes were annotated using the RAST tool kit (RAStk) [22] integrated in PATRIC v.3.5.41 (https://www.patricbrc.org). The circular genomic maps were also obtained from PATRIC v.3.5.41. The whole-genome shotgun projects of strains $\mathrm{T} 13^{\mathrm{T}}, \mathrm{T} 90^{\mathrm{T}}$ and $\mathrm{R} 8^{\mathrm{T}}$ have been deposited in GenBank/EMBL/DDBJ under accession numbers JAAALL000000000, JAAALM000000000 and JAAALN000000000, respectively. The completeness and contamination of the genomes was analysed with the bioinformatic tool CheckM v.1.0.6 [23].

Pairwise average nucleotide identity values (ANIb) [24] were calculated between strains $\mathrm{T} 13^{\mathrm{T}}, \mathrm{T} 90^{\mathrm{T}}$ and $\mathrm{R}^{\mathrm{T}}$ and their closest type strains whose genomes were publicly available, by using the JSpeciesWS online tool [25]. Additionally, digital DNA-DNA hybridization (dDDH) pairwise values were also 
obtained using the Genome-to-Genome Distance Calculator 2.1 (GGDC) tool [26]. As recommended for incompletely sequenced genomes, formula 2 was used for calculating the digital DDH values [26].

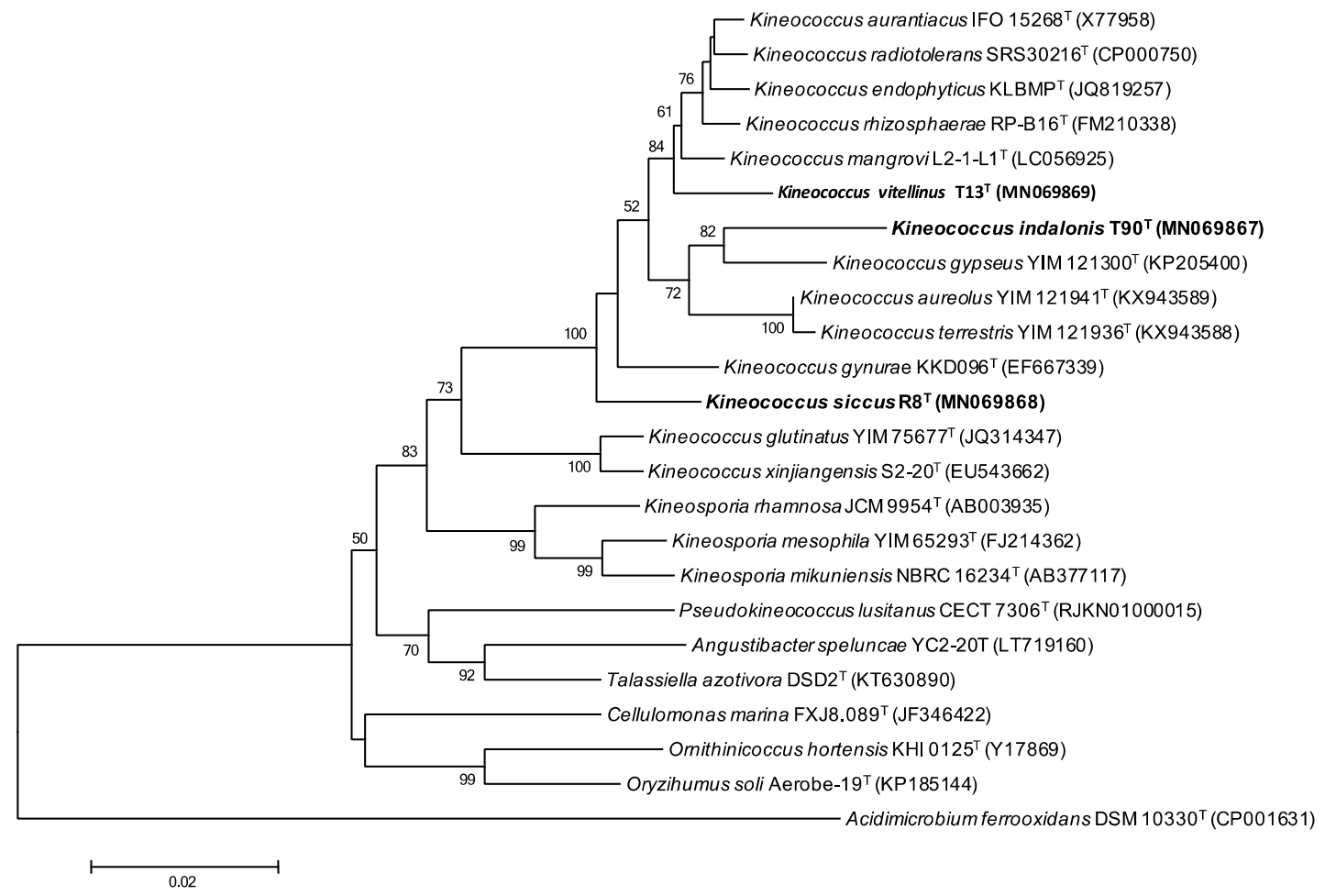

Figure 2. Neighbour-joining phylogenetic tree showing the relationships between strains $\mathrm{T} 13^{\mathrm{T}}, \mathrm{T} 90^{\mathrm{T}}$, $\mathrm{R} 8^{\mathrm{T}}$ and other members of the family Kineosporiaceae based on 16S rRNA sequences. The evolutionary model of nucleotide substitution applied was the Kimura two-parameter model (K2P). Numbers at branch points refer to bootstrap percentages based on 1000 replicates (values under $50 \%$ are not indicated). Acidimicrobium ferrooxidans DSM $10331^{\mathrm{T}}$ (CP001631) was used as an outgroup. Bar 0.02 fixed nucleotide substitutions per site.

\subsection{Morphological and Biochemical Characteristics}

The phenotypic characteristics of the bacterial cultures were determined after one week of growth at $30{ }^{\circ} \mathrm{C}$ on TSA medium following the procedures outlined previously by other authors $[27,28]$. Cell morphology was observed under the microscope with crystal violet glass stain. Motility was analysed on wet mounts. The presence of flagella was determined with the staining method described by Heimbrook et al. [29].

Growth under microaerophilic conditions was tested by incubating the plates in a candle jar. The ability to grow in anaerobiosis was determined with the BD GasPak ${ }^{\mathrm{TM}} \mathrm{EZ}$ pouch system (Becton, Dickinson and Company, Franklin Lakes, NJ, USA). Catalase activity was determined by using $30 \%(v / v)$ $\mathrm{H}_{2} \mathrm{O}_{2}$, recording bubble production as a positive result. Oxidase activity was determined with Oxidase Test Stick for microbiology (PanReac AppliChem, Barcelona, Spain). Gram type was determined by using $\mathrm{KOH} 3 \%(w / v)$, with cell lysis as a positive result for Gram-negative bacteria. Growth at different temperatures $\left(4,10,15,25,30,37,40\right.$ and $\left.45^{\circ} \mathrm{C}\right)$ and at various final $\mathrm{NaCl}$ concentrations $(0.0-4.0 \%$ at intervals of $0.5 \%$, and $4.0-10.0 \%$ at intervals of $1.0 \%$ ) was examined by cultivating the isolates on TSA medium. The ability to grow at different $\mathrm{pH}$ values (4.0-11.0 at intervals of $1.0 \mathrm{pH}$ unit) was examined in TSB using the MES ( $\mathrm{pH} 4-6$ ), HEPES (pH 7-8) and CHES (pH 9-11) buffers at $10 \mathrm{mM}$. Carbon source assimilation and enzymatic activities were determined using the API 20NE and API ZYM system strips (bioMérieux, Marcy-l'Étoile, France) according to manufacturer's instructions, as well as BIOLOG GEN III MicroPlates (BIOLOG Inc., Hayward, CA, USA). 


\subsection{Chemotaxonomic Analysis}

For fatty acid analysis, strains $\mathrm{T} 13^{\mathrm{T}}, \mathrm{T} 90^{\mathrm{T}}, \mathrm{R} 8^{\mathrm{T}}$ and their closest relatives were grown on TSA at $26{ }^{\circ} \mathrm{C}$ for $72 \mathrm{~h}$. Analysis of cellular fatty acids was carried out using the Sherlock Microbial Identification System (version 6.1, MIDI, Inc., Newark, DE, USA) [30]. Fatty acids were analysed on an Agilent 6859 gas chromatography system and using the MIDI method TSBA6 [31], according to the manufacturer's instructions.

\section{Results and Discussion}

\subsection{Phylogenetic Analysis}

The almost-complete 16S rRNA gene sequences showed that the three strains were phylogenetically related to representatives of the genus Kineococcus. According to the EzBioCloud database tool (http://www.ezbiocloud.net/), the closest type strains of $\mathrm{T} 13^{\mathrm{T}}, \mathrm{T} 90^{\mathrm{T}}$ and $\mathrm{R}^{\mathrm{T}}$ are K. aurantiacus IFO $15268^{\mathrm{T}}$ (98.5\% 16S rRNA gene sequence similarity), K. gypseus YIM $121300^{\mathrm{T}}(97.1 \%)$ and K. radiotolerans SRS $30216^{\mathrm{T}}$ (97.9\%), respectively. Since these $16 \mathrm{~S}$ rRNA gene sequence similarities are lower than $98.7 \%$, we have evidence that suggests that the strains $\mathrm{T} 13^{\mathrm{T}}, \mathrm{T} 90^{\mathrm{T}}$ and $\mathrm{R} 8^{\mathrm{T}}$ may belong to new species $[32,33]$. According to these results, K. aurantiacus DSM $7487^{\mathrm{T}}$ and K. radiotolerans DSM $14245^{\mathrm{T}}$ were selected as comparative reference strains for $\mathrm{T} 13^{\mathrm{T}} ;$ K. gypseus DSM $27627^{\mathrm{T}}$, K. aureolus DSM $102158^{\mathrm{T}}$ and K. mangrovi NBRC $110933^{\mathrm{T}}$ for T90 ${ }^{\mathrm{T}}$; and K. radiotolerans DSM $14245^{\mathrm{T}}$, K. aurantiacus DSM $7487^{\mathrm{T}}$ and K. gynurae NBRC $103943^{\mathrm{T}}$ for $\mathrm{R} 8^{\mathrm{T}}$.

The three isolates are classified into the genus Kineococcus in both 16S-rRNA-based phylogenetic trees constructed by ML and NJ. Specifically, $\mathrm{T} 13^{\mathrm{T}}$ showed an external position in the cluster formed by K. aurantiacus IFO $15268^{\mathrm{T}}$, K. mangrovi L2-1-L1 ${ }^{\mathrm{T}}$, K. endophyticus KLBMPT ${ }^{\mathrm{T}}$, K. rhizosphaerae RP-B16 ${ }^{\mathrm{T}}$ and $K$. radiotolerans SRS30216 ${ }^{\mathrm{T}}$ (Figures 1 and 2). Strain $\mathrm{T}^{\mathrm{T}}$ formed a monophyletic group with K. gypseus YIM $121300^{\mathrm{T}}$ (Figures 1 and 2) while strain $\mathrm{R} 8^{\mathrm{T}}$ appeared as an external taxon within the genus Kineococcus (Figures 1 and 2). The phylogenetic inference of the three strains based on the $16 \mathrm{~S}$ rRNA was supported by high bootstrap values.

The ANI and digital DDH values between strains $\mathrm{T} 13^{\mathrm{T}}$ vs. K. radiotolerans SRS $30216^{\mathrm{T}}$ and $\mathrm{R} 8^{\mathrm{T}}$ vs. K. radiotolerans SRS $30216^{\mathrm{T}}$ were $80.6-24.20 \%$ and $77.40-41.73 \%$, respectively. As the values were higher than the threshold established to circumscribe prokaryotic species, namely 95\% for ANI values [34] and $70 \%$ for $\mathrm{dDDH}$ [26], both genome-related indexes [35] confirmed the adscription of strains $\mathrm{T}^{2} 3^{\mathrm{T}}$ and $\mathrm{R} 8^{\mathrm{T}}$ to hitherto unknown species. On the other hand, the closest relative of $\mathrm{T}^{\mathrm{T}} \mathrm{T}$ is $\mathrm{K}$. gypseus YIM $121300^{\mathrm{T}}$. It must be noted that the genome of K. gypseus YIM $121300^{\mathrm{T}}(97.1 \%)$ was not publicly available at the time of writing the manuscript. However, since the $16 \mathrm{~S}$ rRNA gene sequence similarity between $\mathrm{T}^{\mathrm{T}}$ and its closest relative K. gypseus $\mathrm{YIM} 121300^{\mathrm{T}}$ is $<98.7 \%$, it is not necessary to calculate any overall genome relatedness index (OGRI) to propose $\mathrm{T} 90^{\mathrm{T}}$ as an independent genomospecies [32] .

\subsection{Genomic Characteristics}

The circular map highlighting the main genomic features of the three strains is shown in Figures S2-S4. The draft genome of strains $\mathrm{T} 13^{\mathrm{T}}, \mathrm{T} 90^{\mathrm{T}}$ and $\mathrm{R} 8^{\mathrm{T}}$ consisted of 705,1067 and 502 contigs, yielding a total length of 4,857,076, 4,498,067 and 4,581,425 bp, respectively. The genomic $\mathrm{G}+\mathrm{C}$ content of strains $\mathrm{T} 13^{\mathrm{T}}, \mathrm{T} 90^{\mathrm{T}}$ and $\mathrm{R}^{\mathrm{T}}$ was $75.4 \%, 76.3 \%$ and $75.1 \%$, respectively. This genomic $\mathrm{G}+\mathrm{C}$ content is in accordance with other Kineococcus species, and further confirms their adscription to the Kineococcus genus [2,7,8]. A total of 5039, 4690 and 4633 coding sequences (CDSs) were predicted for strains $\mathrm{T} 13^{\mathrm{T}}$, $\mathrm{T}^{\mathrm{T}}{ }^{\mathrm{T}}$ and $\mathrm{R} 8^{\mathrm{T}}$, respectively, of which 1894, 2906 and 2832 were proteins with functional assignments. In the case of tRNA genes, a total of 45 were predicted for strains $T 13^{\mathrm{T}}$ and $\mathrm{R} 8^{\mathrm{T}}$, and 46 were predicted for strain $\mathrm{T} 90^{\mathrm{T}}$. Regarding rRNA genes, six of them were identified in $\mathrm{T} 13^{\mathrm{T}}$; whereas five genes were found for $\mathrm{T} 90^{\mathrm{T}}$ and $\mathrm{R} 8^{\mathrm{T}}$. The genome completeness values of strains $\mathrm{T} 13^{\mathrm{T}}, \mathrm{T} 90^{\mathrm{T}}$ and $\mathrm{R} 8^{\mathrm{T}}$ were $98.9 \%$, $98.1 \%$ and $99.2 \%$, respectively; and the levels of contamination were $1.1 \%, 1.7 \%$ and $0 \%$, respectively. Therefore, the draft genomes showed high enough quality for further analysis [32]. 
By analysing the draft genome of strains $\mathrm{T} 13^{\mathrm{T}}, \mathrm{T} 90^{\mathrm{T}}$ and $\mathrm{R} 8^{\mathrm{T}}$, their ability to synthesise diphosphatidylglycerol and phosphatidylglycerol was predicted based on the presence of genes coding for cardiolipin synthase A/B (EC:2.7.8.-) and ribosomal-protein-serine acetyltransferase (EC 2.3.1.-). However, the synthesis of phosphatidylinositol (EC 2.7.8.11), a major polar lipid of several Kineococcus species, could not be predicted in any of the three genomes $[2,8,11]$. Furthermore, the synthesis of meso-diaminopimelic acid in the three strains was predicted based on the presence of the enzyme diaminopimelate epimerase (EC 5.1.1.7), and the synthesis of menaquinones was predicted based on the identification of the enzyme demethylmenaquinone methyltransferase (EC 2.1.1.163). Therefore, the chemotaxonomic profile of the three new strains is in accordance with other Kineococcus species, corroborating their inclusion into the genus Kineococcus $[2,7,8]$.

\subsection{Phenotypic Characterization}

Strains $\mathrm{T} 13^{\mathrm{T}}, \mathrm{T} 90^{\mathrm{T}}$ and $\mathrm{R} 8^{\mathrm{T}}$ proved to be aerobic, Gram-positive, motile and coccus-shaped $(1 \mu \mathrm{m}$ in diameter). Like other members of the genus Kineococcus, cells of the three strains occur singly, in pairs or in clusters (Figure S1). Cell motility was confirmed by the presence of flagella. Colonies were orange-coloured, with irregular margins and a rough surface. $\mathrm{T} 13^{\mathrm{T}}$ colonies were paler than other Kineococcus strains. $\mathrm{T} 90^{\mathrm{T}}$ colonies changed in colour to dark orange-greenish after incubation at low temperatures (below $15^{\circ} \mathrm{C}$ ). The colonies displayed a diameter of around 1-2 $\mathrm{mm}$ after 3-4 days of growth, although $\mathrm{T} 90^{\mathrm{T}}$ colonies displayed a larger diameter.

All three strains were able to grow between 10 and $30^{\circ} \mathrm{C}$ (optimum $25-30^{\circ} \mathrm{C}$ ). Furthermore, strain $\mathrm{R} 8^{\mathrm{T}}$ was able to grow at $4{ }^{\circ} \mathrm{C}$, while strains $\mathrm{T} 13^{\mathrm{T}}$ and $\mathrm{T} 90^{\mathrm{T}}$ could grow up to 37 and $40^{\circ} \mathrm{C}$, respectively (Table 1). Strains $\mathrm{T} 90^{\mathrm{T}}$ and $\mathrm{R}^{\mathrm{T}}$ could grow at $\mathrm{NaCl}$ concentrations up to $4 \%$, while $\mathrm{T} 13^{\mathrm{T}}$ could grow at concentrations up to $5 \%$ (optimum for the three strains, $0 \% \mathrm{NaCl}$ ). K. radiotolerans DSM $14245^{\mathrm{T}}$, K. aurantiacus DSM $7487^{\mathrm{T}}$, K. gypseus DSM $27627^{\mathrm{T}}$ and K. gynurae NBRC $103943^{\mathrm{T}}$ showed a salinity tolerance range similar to our strains, while K. aureolus DSM $102158^{\mathrm{T}}$ and K. mangrovi NBRC $110933^{\mathrm{T}}$ were able to grow at concentrations up to $8 \%$ and $9 \% \mathrm{NaCl}$, respectively (Table 1). Even though the three strains were found to be neutrophilic (optimum growth at $\mathrm{pH} 7$ ), strains $\mathrm{T} 13^{\mathrm{T}}$ and $\mathrm{T} 90^{\mathrm{T}}$ were able to grow at alkaline values (up to $\mathrm{pH} 9$ and 10, respectively), whereas $\mathrm{R} 8^{\mathrm{T}}$ could grow weakly at pH 5. Other Kineococcus species such as K. aureolus DSM $102158^{\mathrm{T}}$, K. aurantiacus DSM $7487^{\mathrm{T}}$, K. gypseus DSM $27627^{\mathrm{T}}$, K. mangrovi NBRC $110933^{\mathrm{T}}$ and K. gynurae NBRC $103943^{\mathrm{T}}$ were able to tolerate alkaline $\mathrm{pH}$ (Table 1). All three strains were able to grow under microaerophilic conditions, but no growth was observed for any of them in anaerobiosis.

Strains $\mathrm{T} 13^{\mathrm{T}}, \mathrm{T} 90^{\mathrm{T}}$ and $\mathrm{R} 8^{\mathrm{T}}$, like their closest relatives, showed a positive response for esculin hydrolysis, $\beta$-galactosidase, esterase (C4), esterase lipase (C8), leucine arylamidase, $\alpha$-chymotrypsin, acid phosphatase, naphthol-AS-BI-phosphohydrolase and $\beta$-glucosidase. On the other hand, strains $\mathrm{T} 13^{\mathrm{T}}, \mathrm{T} 90^{\mathrm{T}}$ and $\mathrm{R} 8^{\mathrm{T}}$ and their closest neighbours showed a negative response for nitrate reduction, indole production, glucose fermentation, arginine dihydrolysis and $\mathrm{N}$-acetyl- $\beta$-glucosaminidase. Strains $\mathrm{R} 8^{\mathrm{T}}$ and K. gynurae NBRC $103943^{\mathrm{T}}$ showed urease activity, while strain $\mathrm{T} 90^{\mathrm{T}}$, K. gynurae NBRC $103943^{\mathrm{T}}$, K. aureolus DSM $102158^{\mathrm{T}}$ and K. gypseus DSM $27627^{\mathrm{T}}$ were able to hydrolyse gelatine (Table 1). In API $20 \mathrm{NE}$ strips, strain $\mathrm{R}^{\mathrm{T}}$ proved able to use all the saccharides tested (Table 1). On the contrary, strain $\mathrm{T} 13^{\mathrm{T}}$ was only able to grow weakly with glucose, while $\mathrm{T} 90^{\mathrm{T}}$ could not grow in any of the carbon sources tested. Furthermore, BIOLOG assays revealed that strains $\mathrm{T} 13^{\mathrm{T}}, \mathrm{T} 90^{\mathrm{T}}$ and $\mathrm{R} 8^{\mathrm{T}}$ were able to oxidize 31, 62 and 26 out of the 71 tested carbon sources, respectively, and these were mainly organic acids and amino acids (Table S1). This suggests that strain $\mathrm{T} 90^{\mathrm{T}}$ displays a more polytrophic metabolism than strains $\mathrm{T} 13^{\mathrm{T}}$ and $\mathrm{R} 8^{\mathrm{T}}$. 
Table 1. Differential characteristics between strains $\mathrm{T} 13^{\mathrm{T}}, \mathrm{T} 90^{\mathrm{T}}, \mathrm{R} 8^{\mathrm{T}}$ and related type strains of the genus Kineococcus

\begin{tabular}{|c|c|c|c|c|c|c|c|c|c|}
\hline Characteristic & 1 & 2 & 3 & 4 & 5 & 6 & 7 & 8 & 9 \\
\hline Isolation source & Biocrust & Biocrust & Biocrust & $\begin{array}{c}\text { Radioactive } \\
\text { work area [11] }\end{array}$ & $\begin{array}{c}\text { Saline } \\
\text { sediment [8] }\end{array}$ & Soil [1] & $\begin{array}{c}\text { Saline } \\
\text { sediment [6] }\end{array}$ & $\begin{array}{c}\text { Mangrove } \\
\text { sediment [7] }\end{array}$ & $\begin{array}{r}\text { Medicinal } \\
\text { plant [9] }\end{array}$ \\
\hline Growth at/in: & & & & & & & & & \\
\hline Temperature range $\left({ }^{\circ} \mathrm{C}\right)$ & $10-37$ & $10-40$ & $4-30$ & $4-37$ & $10-45$ & $4-40$ & $15-37$ & $10-30$ & $4-30$ \\
\hline $\mathrm{pH}$ range & $6-9$ & $6-10$ & $5-8$ & $6-8$ & $7-11$ & $5-9$ & $5-10$ & $5-9$ & $5-10$ \\
\hline $\mathrm{NaCl}$ tolerance $(\%, w / v)$ & $0-5$ & $0-4$ & $0-4$ & $0-4$ & $0-8$ & $0-4$ & $0-4$ & $0-9$ & $0-6$ \\
\hline \multicolumn{10}{|l|}{$\begin{array}{c}\text { Carbon source utilization } \\
\text { (API 20NE) }\end{array}$} \\
\hline D-Glucose & $\mathrm{W}$ & - & + & + & + & + & + & + & + \\
\hline L-Arabinose & - & - & + & + & + & + & + & + & + \\
\hline D-Mannose & - & - & + & + & + & + & + & + & + \\
\hline D-Mannitol & - & - & + & + & + & + & $\mathrm{W}$ & + & + \\
\hline N-Acetyl-glucosamine & - & - & + & $\mathrm{W}$ & - & + & - & $\mathrm{W}$ & - \\
\hline D-Maltose & - & - & + & $\mathrm{W}$ & + & + & $\mathrm{W}$ & + & + \\
\hline Potassium gluconate & - & - & W & + & + & $\mathrm{W}$ & - & + & W \\
\hline Adipic acid & - & - & $\mathrm{W}$ & $\mathrm{W}$ & $\mathrm{W}$ & - & - & - & - \\
\hline Malic acid & - & - & - & $\mathrm{W}$ & + & - & $\mathrm{W}$ & + & $\mathrm{W}$ \\
\hline Trisodium citrate & - & - & - & - & $\mathrm{W}$ & - & - & - & $\mathrm{W}$ \\
\hline Phenylacetic acid & - & - & - & - & $\mathrm{W}$ & - & - & - & - \\
\hline \multicolumn{10}{|l|}{ Enzymatic activity (API 20NE) } \\
\hline Urease & - & - & + & - & - & - & - & - & + \\
\hline Gelatinase & - & + & - & - & + & - & + & - & + \\
\hline \multicolumn{10}{|l|}{ Enzymatic activity (API ZYM) } \\
\hline Alkaline phosphatase & - & + & + & + & - & + & - & + & + \\
\hline Lipase (C14) & - & - & - & + & - & - & - & - & - \\
\hline Valine arylamidase & + & + & + & + & + & + & + & - & - \\
\hline Cystine arylamidase & - & - & + & + & - & + & + & - & - \\
\hline Trypsin & - & - & - & + & - & - & - & - & - \\
\hline$\alpha$-Galactosidase & + & + & + & + & + & + & - & + & + \\
\hline$\beta$-Glucuronidase & - & - & - & + & - & - & - & - & - \\
\hline$\alpha$-Glucosidase & + & + & - & + & - & - & + & + & + \\
\hline$\alpha$-Manosidase & + & + & - & - & + & + & - & - & + \\
\hline$\alpha$-Fucosidase & + & - & + & - & + & - & - & - & - \\
\hline
\end{tabular}

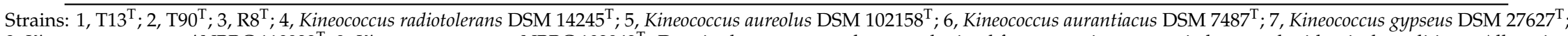
8, Kineococcus mangrovi NBRC $110933^{\mathrm{T}}$; 9, Kineococcus gynurae NBRC $103943^{\mathrm{T}}$. Data in the present study were obtained from experiments carried out under identical conditions. All strains were positive for the following characteristics: Gram reaction, catalase activity, esculin hydrolysis, $\beta$-galactosidase, esterase (C4), esterase lipase (C8), leucine arylamidase, $\alpha$-chymotrypsin, acid phosphatase, naphthol-AS-BI-phosphohydrolase and $\beta$-glucosidase. All strains were negative for the following characteristics: oxidase, nitrate reduction, indole formation, glucose fermentation, arginine dihydrolysis, capric acid assimilation and $\mathrm{N}$-acetyl- $\beta$-glucosaminidase. + , positive; -, negative; $\mathrm{W}$, weak reaction. 
The major fatty acids for strains $\mathrm{T} 13^{\mathrm{T}}, \mathrm{T} 90^{\mathrm{T}}$ and $\mathrm{R} 8^{\mathrm{T}}$ were anteiso- $\mathrm{C}_{15: 0}(96.1 \%, 73.9 \%$ and $94.0 \%$, respectively). Similarly, their closest relatives showed high amounts of anteiso- $\mathrm{C}_{15: 0}$ (Table 2), corroborating the inclusion of the three strains in the genus Kineococcus $[2,8,11]$. The presence of anteiso- $\mathrm{C}_{15: 0}$ fatty acid in the cell membranes has been associated with resistance to low temperatures [36,37]. In fact, this fatty acid has been found in the psychrophilic members of the genus Flavobacterium [38] isolated from a cold desert environment. Moreover, anteiso- $\mathrm{C}_{15: 0}$ fatty acid can play an important role in biofilm formation $[39,40]$, which is in accordance with the biofilms and cell clumps observed for the three Kineococcus strains under liquid growth conditions.

Table 2. Cellular fatty acid composition of strains $\mathrm{T} 13^{\mathrm{T}}, \mathrm{T} 90^{\mathrm{T}}$ and $\mathrm{R} 8^{\mathrm{T}}$ and their closest relatives.

\begin{tabular}{|c|c|c|c|c|c|c|c|c|c|}
\hline Fatty Acids & 1 & 2 & 3 & 4 & 5 & 6 & 7 & 8 & 9 \\
\hline \multicolumn{10}{|l|}{ Saturated } \\
\hline $\mathrm{C}_{14: 0}$ & $\operatorname{tr}$ & 1.2 & 1.37 & - & 1.8 & 1.3 & 2.1 & 3.9 & 1.6 \\
\hline iso- $C_{14: 0}$ & - & 1.7 & 1.34 & - & 2.0 & & 1.8 & 7.1 & 2.9 \\
\hline $\mathrm{C}_{15: 0}$ & - & $\operatorname{tr}$ & - & - & 1.7 & 1.0 & 2.6 & - & 2.2 \\
\hline iso- $C_{15: 0}$ & $\operatorname{tr}$ & 1.3 & - & - & $\operatorname{tr}$ & - & - & - & - \\
\hline anteiso- $C_{15: 0}$ & 96.1 & 73.9 & 94.0 & 97.9 & 78.8 & 75.9 & 73.0 & 84.4 & 74.2 \\
\hline$C_{16: 0}$ & - & $\operatorname{tr}$ & $\operatorname{tr}$ & - & 2.0 & 1.8 & 2.2 & $\operatorname{tr}$ & 1.8 \\
\hline $\mathrm{C}_{18: 0}$ & - & - & $\operatorname{tr}$ & - & $\operatorname{tr}$ & 1.5 & 1.2 & - & - \\
\hline \multicolumn{10}{|l|}{ Unsaturated } \\
\hline AT $12-13 C_{13: 1}$ & - & - & - & - & - & 3.4 & - & - & 3.4 \\
\hline anteiso- $C_{15: 1} A$ & 2.6 & 16.9 & - & $\operatorname{tr}$ & 6.7 & - & 12.3 & - & - \\
\hline \multicolumn{10}{|l|}{ Hydroxylated } \\
\hline $\mathrm{C}_{14: 0} 2-\mathrm{OH}$ & - & - & - & - & - & 5.4 & - & $\operatorname{tr}$ & 4.0 \\
\hline $\mathrm{C}_{17: 0} 2-\mathrm{OH}$ & - & - & - & - & - & - & - & 2.8 & - \\
\hline $\mathrm{C}_{17: 0} 3-\mathrm{OH}$ & - & 3.4 & $\operatorname{tr}$ & 1.2 & 3 & 2.4 & 3.5 & - & 1.3 \\
\hline \multicolumn{10}{|l|}{ Summed * } \\
\hline Sum in feature 2 & - & - & - & - & - & 2.7 & - & - & 2.8 \\
\hline Sum in feature 3 & - & - & - & - & - & 2.7 & - & - & 2.4 \\
\hline Sum in feature 5 & - & - & - & - & - & 2.0 & - & - & - \\
\hline
\end{tabular}

* Summed features represent groups of fatty acids that cannot be separated with the chromatographic system. Sum in feature 2 corresponds to $\mathrm{C}_{13: 0} 3-\mathrm{OH} /$ iso- $_{15: 1} \mathrm{I} /$ iso- $\mathrm{C}_{15: 1} \mathrm{H}$. Sum in feature 3 corresponds to iso- $\mathrm{C}_{16: 1} \mathrm{I} / \mathrm{C}_{14: 0}$ $3-\mathrm{OH} / \mathrm{C}_{12: 0}$ alde? Sum in feature 5 corresponds to iso- $\mathrm{C}_{17: 1} \mathrm{I} /$ anteiso- $\mathrm{C}_{17: 1}$ B.; Strains: $1, \mathrm{~T}^{\mathrm{T}}{ }^{\mathrm{T}} ; 2, \mathrm{~T} 90^{\mathrm{T}} ; 3$, R8 ${ }^{\mathrm{T}}$; 4, Kineococcus radiotolerans DSM $14245^{\mathrm{T}} ; 5$, Kineococcus aureolus DSM $102158^{\mathrm{T}} ; 6$, Kineococcus aurantiacus DSM $7487^{\mathrm{T}}$; 7, Kineococcus gypseus DSM $27627^{\mathrm{T}} ; 8$, Kineococcus mangrovi NBRC $110933^{\mathrm{T}} ; 9$, Kineococcus gynurae NBRC $103943^{\mathrm{T}}$. Data for reference strains were obtained in the present study. Values are shown as percentages. - means not detected; tr, $<1.0 \%$ trace.

Unlike their closest relatives, strains $\mathrm{T} 90^{\mathrm{T}}$ and K. gypseus DSM $27627^{\mathrm{T}}$ also showed high amounts of anteiso- $C_{15: 1}(16.9 \%)$ (Table 2). Furthermore, the presence or absence of other minor fatty acids allowed us to differentiate the new strains from their closest neighbours (Table 2).

\section{Conclusions}

During a study on the microbial communities associated with biocrust in sun-exposed and dry surfaces, the three strains $\mathrm{T} 13^{\mathrm{T}}, \mathrm{T} 90^{\mathrm{T}}$ and $\mathrm{R} 8^{\mathrm{T}}$ were isolated in pure culture. All three strains, which were phylogenetically related to the genus Kineococcus, were characterized using a polyphasic approach. According to the phenotypic, genomic and phylogenetic analyses, strains $\mathrm{T} 13^{\mathrm{T}}, \mathrm{T} 90^{\mathrm{T}}$ and $\mathrm{R} 8^{\mathrm{T}}$ should be considered as new species within the Kineococcus genus, for which the names Kineococcus vitellinus sp. nov., Kineococcus indalonis sp. nov. and Kineococcus siccus sp. nov., respectively, are proposed.

\subsection{Description of Kineococcus vitellinus sp. nov.}

Kineococcus vitellinus (vi.tel.li'nus. N.L. masc. adj. Vitellinus Egg-Yolk-Coloured)

Cells are Gram-positive, motile, non-endospore-forming, catalase-positive, oxidase-negative cocci $(1 \mu \mathrm{m}$ in diameter). Cells occur singly, in pairs or in clusters. Colonies are 1-1.5 $\mathrm{mm}$ in diameter, circular, rough and pale orange. Temperature range for growth is $10-37^{\circ} \mathrm{C}$, with an optimum at $25-30^{\circ} \mathrm{C}$. Growth occurs 
at $\mathrm{pH}$ 6-9 (optimum $\mathrm{pH} 7.0$ ) and tolerates up to $5 \% \mathrm{NaCl}(w / v)$, with optimum at $0 \% \mathrm{NaCl}(w / v)$. Esculin hydrolysis, $\beta$-galactosidase, esterase (C4), esterase lipase (C8), leucine arylamidase, $\alpha$-chymotrypsin, acid phosphatase, naphthol-AS-BI-phosphohydrolase, $\beta$-glucosidase, valine arylamidase, $\alpha$-galactosidase, $\alpha$-glucosidase, $\alpha$-mannosidase and $\alpha$-fucosidase activities are detected. Nitrate reduction, indole production, glucose fermentation, arginine dihydrolysis, urease, gelatinase, alkaline phosphatase, lipase (C14), cystine arylamidase, trypsin, $\beta$-glucuronidase and $\mathrm{N}$-acetyl- $\beta$-glucosaminidase are not detected. Using API 20NE test kit, this species is weakly positive for the assimilation of glucose and negative for arabinose, mannitol, $\mathrm{N}$-acetyl-glucosamine, maltose, potassium gluconate, malic acid, mannose, capric acid, adipic acid, trisodium citrate and phenylacetic acid. Using BIOLOG GENIII MicroPlates, this species is positive for the utilization of D-raffinose, $\alpha$ - D-glucose, D-sorbitol, pectin, Tween 40, dextrin, $\alpha$-D-lactose, D-mannose, D-mannitol, D-maltose, D-melibiose, D-fructose, L-alanine, D-trehalose, $\beta$-methyl-D-glucoside, D-galactose, myo-inositol, D-cellobiose, D-salicin, glycerol, gentiobiose, $\mathrm{N}$-acetyl-D-glucosamine, glucuronamide, acetoacetic acid, sucrose, D-fructose-6 $\mathrm{PO}_{4}$, D -turanose, L-rhamnose, L-pyroglutamic acid, stachyose and L-serine; and negative for the utilization of gelatine, p-hydroxy-phenylacetic acid, glycyl- L-proline, D-galacturonic acid, methyl pyruvate, $\gamma$-amino-butyric acid, D-arabitol, L-galactonic acid lactone, D-lactic acid methyl ester, $\alpha$-hydroxy-butyric acid, L-arginine, D-gluconic acid, L-lactic acid, $\beta$-hydroxy- D, L-butyric acid, 3-methylD-glucoside, L-aspartic acid, D-glucuronic acid, citric acid, $\alpha$-keto-butyric acid, D-fucose, D -glucose-6-PO L-glutamic acid, $\beta$-keto-glutaric acid, N-acetyl- $\beta$-D-mannosamine, L-fucose, L-histidine, mucic acid, D-malic acid, propionic acid, N-acetyl-D-galactosamine, D-aspartic acid, quinic acid, L-malic acid, acetic acid, N-acetyl neuraminic acid, inosine, D-serine, D-saccharic acid, bromo-succinic acid and formic acid. The major fatty acid is anteiso- $C_{15: 0}$. The type strain $\mathrm{T}^{\mathrm{T}}{ }^{\mathrm{T}}\left(\mathrm{CECT} 9936^{\mathrm{T}}=\mathrm{DSM} 110024^{\mathrm{T}}\right)$ was isolated nearby the Tabernas Desert in Almería (Spain), from biocrust samples. The G + C content of the type strain is $75.4 \%$. The GenBank/EMBL/DDBJ accession number for the 16S rRNA sequence is MN069869, and the genome accession number is JAAALL000000000.

\subsection{Description of Kineococcus indalonis sp. nov.}

Kineococcus indalonis (in.da.lo'nis. N.L. gen. n. indalonis of Indalo, Which Is a Prehistoric Symbol Found in Rock Paintings in Almería (Spain), Referring to the Place Where the Microorganism Was Isolated)

Cells are Gram-positive, motile, non-endospore-forming, catalase-positive, oxidase-negative cocci ( $1 \mu \mathrm{m}$ in diameter). Cells occur singly, in pairs or in clusters. Colonies are small (1 mm in diameter), circular with irregular margins, rough and pale orange, but below $20^{\circ} \mathrm{C}$ the colour changes from orange to dark greenish. Temperature range for growth is $10-40{ }^{\circ} \mathrm{C}$, with an optimum at $25-30{ }^{\circ} \mathrm{C}$. No growth is observed below 10 or above $40^{\circ} \mathrm{C}$. Growth occurs at $\mathrm{pH}$ 6-10 (optimum, 6-9) and tolerates up to $4 \% \mathrm{NaCl}(w / v)$, with optimum at $0 \%(w / v)$. Esculin hydrolysis, $\beta$-galactosidase, gelatinase, esterase (C4), esterase lipase (C8), leucine arylamidase, $\alpha$-chymotrypsin, acid phosphatase, alkaline phosphatase, valine arylamidase, $\alpha$-galactosidase, naphthol-AS-BI-phosphohydrolase, $\alpha$-glucosidase, $\alpha$-mannosidase and $\beta$-glucosidase activities are detected. Nitrate reduction, indole production, glucose fermentation, arginine dihydrolysis, urease, lipase (C14), cystine arylamidase, trypsin, $\beta$-glucuronidase, $\alpha$-fucosidase and N-acetyl- $\beta$-glucosaminidase are not detected. Using API $20 \mathrm{NE}$ test kit, this species is negative for the assimilation of glucose, arabinose, mannitol, N-acetyl-glucosamine, maltose, potassium gluconate, malic acid, mannose, capric acid, adipic acid, trisodium citrate and phenylacetic acid. Using BIOLOG GENIII MicroPlates, this species is positive for the utilization of D-raffinose, $\alpha$-D-glucose, D-sorbitol, gelatine, pectin, Tween 40, dextrin, $\alpha$ - D-lactose, D-mannose, D-mannitol, glycyl-L-proline, D-galacturonic acid, $\gamma$-amino-butyric acid, D-maltose, D-melibiose, D-fructose, D-arabitol, L-alanine, L-galactonic acid lactone, D-lactic acid methyl ester, D-trehalose, $\beta$-methyl-D-glucoside, D-galactose, myo-inositol, L-arginine, D-gluconic acid, $\beta$-hydroxy-D,L-butyric acid, D-cellobiose, D-salicin, 3-methylD-glucoside, glycerol, L-aspartic acid, D-glucuronic acid, citric acid, $\alpha$-keto-butyric acid, gentiobiose, $\mathrm{N}$-acetyl-D-glucosamine, D-fucose, D-glucose-6- $\mathrm{PO}_{4}$, L-glutamic acid, glucuronamide, $\alpha$-keto-glutaric acid, acetoacetic acid, sucrose, N-acetyl- $\beta$-D-mannose, $\mathrm{L}$-fucose, $\mathrm{D}$-fructose- $6 \mathrm{PO}_{4}$, L-histidine, mucic acid, D-malic acid, propionic acid, D-turanose, N-acetyl-D-galactosamine, L-rhamnose, D-aspartic acid, 
L-pyroglutamic acid, L-malic acid, acetic acid, stachyose, D-serine, L-serine and bromo-succinic acid; and negative for the utilization of p-hydroxy-phenylacetic acid, methyl pyruvate, $\alpha$-hydroxy-butyric acid, L-lactic acid, quinic acid, $\mathrm{N}$-acetyl neuraminic acid, inosine, $\mathrm{D}$-saccharic acid and formic acid. The major fatty acids for strain $\mathrm{T} 90^{\mathrm{T}}$ are anteiso- $\mathrm{C}_{15: 0}$ and anteiso- $\mathrm{C}_{15: 1}$ A. The type strain $\mathrm{T} 90^{\mathrm{T}}$ (CECT $9938^{\mathrm{T}}=$ DSM $110026^{\mathrm{T}}$ ) was first isolated nearby the Tabernas Desert in Almería (Spain), from biocrust samples. The $\mathrm{G}+\mathrm{C}$ content of the type strain is $76.3 \%$. The GenBank/EMBL/DDBJ accession number for the 16S rRNA sequence is MN069867, and the genome accession number is JAAALM000000000.

\subsection{Description of Kineococcus siccus sp. nov.}

Kineococcus siccus (siccus. L. masc. adj. Siccus, Dry)

Cells are Gram-positive, motile, non-endospore-forming, catalase-positive, oxidase-negative cocci $(1 \mu \mathrm{m}$ in diameter). Cells occur singly, in pairs or in clusters. Colonies are orange, circular, with irregular margins and variable size (1-2 mm diameter). Temperature range for growth is $4-30{ }^{\circ} \mathrm{C}$ with an optimum at $25-30{ }^{\circ} \mathrm{C}$. No growth is observed at $40{ }^{\circ} \mathrm{C}$. Growth occurs at $\mathrm{pH}$ 5-8 (optimum $6-7$ ) and tolerates up to $4 \% \mathrm{NaCl}(w / v)$, with optimum at $0 \%(w / v)$. Esculin hydrolysis, $\beta$-galactosidase, urease, esterase (C4), esterase lipase (C8), leucine arylamidase, $\alpha$-chymotrypsin, acid phosphatase, alkaline phosphatase, valine arylamidase, cystine arylamidase, $\alpha$-galactosidase, naphthol-AS-BI-phosphohydrolase, $\alpha$-fucosidase and $\beta$-glucosidase activities are detected. Nitrate reduction, indole production, glucose fermentation, arginine dihydrolysis, gelatinase, lipase (C14), trypsin, $\alpha$-glucosidase, $\beta$-glucuronidase, $\alpha$-mannosidase and $N$-acetyl- $\beta$-glucosaminidase are not detected. Using API 20NE test kit, this species is positive for the assimilation of glucose, arabinose, mannose, mannitol, $\mathrm{N}$-acetyl-glucosamine and maltose; weak for the assimilation potassium gluconate and adipic acid and negative for the assimilation of malic acid, capric acid, trisodium citrate and phenylacetic acid. Using BIOLOG GENIII MicroPlates, this species is positive for the utilization of pectin, Tween 40, dextrin, D-fructose, D-arabitol, L-alanine, D-galactose, D-gluconic acid, L-lactic acid, D-cellobiose, 3-methyl-D-glucoside, glycerol, D-glucuronic acid, gentiobiose, glucuronamide, acetoacetic acid, $\mathrm{L}$-fucose, $\mathrm{D}$-fructose-6- $\mathrm{PO}_{4}$, mucic acid, D-malic acid, D-turanose, D-aspartic acid, quinic acid, L-malic acid, acetic acid and D-serine; and negative for the utilization of D-raffinose, $\alpha$-D-glucose, D-sorbitol, gelatine, p-hydroxy-phenylacetic acid, $\alpha$-D-lactose, D-mannose, D-mannitol, glycyl-L-proline, D-galacturonic acid, methyl pyruvate, $\gamma$-amino-butyric acid, D-maltose, D-melibiose, L-galactonic acid lactone, D-lactic acid methyl ester, $\alpha$-hydroxy-butyric acid, D-trehalose, $\beta$-methyl-D-glucoside, myo-inositol, L-arginine, $\beta$-hydroxy-D,L-butyric acid, D-salicin, L-aspartic acid, citric acid, $\alpha$-keto-butyric acid, N-acetyl-D-glucosamine, D-fucose, D-glucose-6- $\mathrm{PO}_{4}$, L-glutamic acid, $\alpha$-keto-glutaric acid, sucrose, $\mathrm{N}$-acetyl- $\beta$-D-mannose, L-histidine, propionic acid, $\mathrm{N}$-acetyl-D-galactosamine, L-rhamnose, L-pyroglutamic acid, stachyose, $\mathrm{N}$-acetyl neuraminic acid, inosine, L-serine, D-saccharic acid, bromo-succinic acid and formic acid. The major fatty acid is anteiso- $\mathrm{C}_{15: 0}$. The type strain $\mathrm{R} 8^{\mathrm{T}}$ $\left(\right.$ CECT $9937^{\mathrm{T}}=$ DSM $\left.110025^{\mathrm{T}}\right)$ was first isolated nearby the Tabernas Desert in Almería (Spain), from biocrust samples. The $\mathrm{G}+\mathrm{C}$ content of the type strain is $75.1 \%$. The GenBank/EMBL/DDBJ accession number for the 16S rRNA sequence is MN069868, and the genome accession number is JAAALN000000000.

Supplementary Materials: The following are available online at http://www.mdpi.com/2076-2607/8/10/1547/s1, Table S1: Carbon source utilization comparison using GENIII MicroPlates of strains $\mathrm{T} 13^{\mathrm{T}}, \mathrm{T} 90^{\mathrm{T}}, \mathrm{R}^{\mathrm{T}}$ and the type strains of closely related Kineococcus species. Figure S1: Cell morphology of strains $\mathrm{T}^{\mathrm{T}} 3^{\mathrm{T}}(\mathrm{A}, \mathrm{B}), \mathrm{T}^{\mathrm{T}}{ }^{\mathrm{T}}(\mathrm{C}, \mathrm{D})$ and $\mathrm{R} 8^{\mathrm{T}}$ (E, F) under the optical microscope at 100× magnification, Figure S2: Kineococcus vitellinus sp. nov. $\mathrm{T} 13^{\mathrm{T}}$ circular genomic map. Figure S3: Kineococcus indalonis sp. nov. ${ }^{2} 90^{\mathrm{T}}$ circular genomic map. Figure S4: Kineococcus siccus sp. nov. $\mathrm{R}^{\mathrm{T}}$ circular genomic map.

Author Contributions: M.P. conceived the work. M.P., E.M.-M. and H.G.-V. carried out the sampling. E.M.-M. and H.G.-V. performed the identification. E.M.-M. carried out the phenotypic characterization. J.P. (Javier Pascual) supervised the bioinformatic and phylogenetic analysis. E.M.-M., H.G.-V., J.P. (Javier Pascual), J.P. (Juli Peretó) and 
M.P. analysed the results, wrote and approved the manuscript. All authors have read and agreed to the published version of the manuscript.

Funding: Financial support from Spanish Government (Grant HELIOS with reference: BIO2015-66960-C3-1-R; and grant SETH with reference RTI2018-095584-B-C41-42-43-44 co-financed by FEDER funds and Ministerio de Ciencia, Innovación y Universidades) is acknowledged. EMM is a recipient of a Formación del Profesorado Universitario (FPU) grant with reference FPU17/04184, from the Ministerio de Ciencia, Innovación y Universidades (Spain).

Acknowledgments: We acknowledge Aharon Oren from the Hebrew University of Jerusalem for his advice with the name of the species. We also thank Adriel Latorre from Darwin Bioprospecting Excellence SL for his help with the genomic analysis.

Conflicts of Interest: The authors declare no conflict of interest. The funders had no role in the design of the study; in the collection, analyses, or interpretation of data; in the writing of the manuscript; or in the decision to publish the results.

\section{References}

1. Zhi, X.Y.; Li, W.J.; Stackebrandt, E. An update of the structure and 16S rRNA gene sequence-based definition of higher ranks of the class Actinobacteria, with the proposal of two new suborders and four new families and emended descriptions of the existing higher taxa. Int. J. Syst. Evol. Microbiol. 2009, 59, 589-608. [CrossRef] [PubMed]

2. Yokota, A.; Tamura, T.; Nishii, T.; Hasegawa, T. Kineococcus aurantiacus gen. nov., sp. nov., a New Aerobic, Gram-Positive, Motile Coccus with meso-Diaminopimelic Acid and Arabinogalactan in the Cell Wall. Int. J. Syst. Bacteriol. 1993, 43, 52-57. [CrossRef]

3. Lee, S.D. Kineococcus rhizosphaerae sp. nov., isolated from rhizosphere soil. Int. J. Syst. Evol. Microbiol. 2009, 59, 2204-2207. [CrossRef] [PubMed]

4. Liu, M.; Peng, F.; Wang, F.; Zhang, K.L.; Chen, G.; Fang, C. Kineococcus xinjiangensis sp. nov., isolated from desert sand. Int. J. Syst. Evol. Microbiol. 2009, 59, 1090-1093. [CrossRef]

5. Nie, G.-X.; Ming, H.; Zhang, J.; Feng, H.-G.; Li, S.; Yu, T.-T.; Zhou, E.-M.; Tang, S.-K.; Li, W.-J. Kineococcus glutineturens sp. nov., isolated from soil in yunnan, south-west china. Anton. Leeuw. Int. J. G. 2012, 102, 239-246. [CrossRef]

6. Li, Q.; Li, G.-D.; Chen, X.; Xu, F.; Li, Y.; Xu, L.; Jiang, Y.; Jiang, C. Kineococcus gypseus sp. nov., isolated from saline sediment. Int. J. Syst. Evol. Microbiol. 2015, 65, 3703-3708. [CrossRef]

7. Duangmal, K.; Muangham, S.; Mingma, R.; Yimyai, T.; Srisuk, N.; Kitpreechavanich, V.; Matsumoto, A.; Takahashi, Y. Kineococcus mangrovi sp. nov., isolated from mangrove sediment. Int. J. Syst. Evol. Microbiol. 2016, 66, 230-1235. [CrossRef]

8. Xu, F.J.; Li, Q.Y.; Li, G.D.; Chen, X.; Jiang, Y.; Jiang, C.L. Kineococcus terrestris sp. nov. and Kineococcus aureolus sp. nov., isolated from saline sediment. Int. J. Syst. Evol. Microbiol. 2017, 67, 4801-4807. [CrossRef]

9. Duangmal, K.; Thamchaipenet, A.; Ara, I.; Matsumoto, A.; Takahashi, Y. Kineococcus gynurae sp. nov., isolated from a Thai medicinal plant. Int. J. Syst. Evol. Microbiol. 2008, 58, 2439-2442. [CrossRef]

10. Bian, G.K. Kineococcus endophytica sp. nov., a novel endophytic actinomycete isolated from a coastal halophyte in Jiangsu, China. Anton. Leeuw. 2012, 102, 621-628. [CrossRef]

11. Phillips, R.W.; Wiegel, J.; Berry, C.J.; Fliermans, C.; Peacock, A.D.; White, D.C.; Shimkets, L.J. Kineococcus radiotolerans sp. nov., a radiation-resistant, Gram-positive bacterium. Int. J. Syst. Evol. Microbiol. 2002, 52, 933-938. [PubMed]

12. Normand, P.; Benson, D.R. Kineococcus. In Bergey's Manual of Systematics of Archaea and Bacteria; Whitman, W.B., Rainey, F., Kämpfer, P., Trujillo, M., Chun, J., DeVos, P., Hedlund, B., Dedysh, S., Eds.; John Wiley \& Sons, Inc.: Hoboken, NJ, USA, 2015. [CrossRef]

13. Tanner, K.; Martorell, P.; Genovés, S.; Ramón, D.; Zacarías, L.; Rodrigo, M.J.; Peretó, J.; Porcar, M. Bioprospecting the solar panel microbiome: High-throughput screening for antioxidant bacteria in a Caenorhabditis elegans model. Front. Microbiol. 2019, 10, 986. [CrossRef] [PubMed]

14. Molina-Menor, E.; Tanner, K.; Vidal-Verdú, À.; Peretó, J.; Porcar, M. Microbial communities of the Mediterranean rocky shore: Ecology and biotechnological potential of the sea-land transition. Microb. Biotechnol. 2019, 12, 1359-1370. [CrossRef] [PubMed] 
15. Edwards, U.; Rogall, T.; Blöcker, H.; Emde, M.; Böttger, E.C. Isolation and direct complete nucleotide determination of entire genes: Characterization of a gene coding for $16 \mathrm{~S}$ ribosomal RNA. Nucleic Acids Res. 1989, 17, 7843-7853. [CrossRef] [PubMed]

16. Stackebrandt, E.; Liesack, W. Nucleic acids and classification. In Handbook of New Bacterial Systematics; Goodfellow, M., O’Donnell, A.G., Eds.; Academic Press: London, UK, 1993; pp. 152-189.

17. Felsenstein, J. Evolutionary trees from DNA sequences: A maximum likelihood approach. J. Mol. Evol. 1981, 17, 368-376. [CrossRef]

18. Saitou, N.; Nei, M. The neighbor-joining method: A new method for reconstructing phylogenetic trees. Mol. Biol. Evol. 1897, 4, 406-425.

19. Felsenstein, J. Confidence limits on phylogenies: An approach using the bootstrap. Evolution 1985, 39, 783-791. [CrossRef]

20. Andrews, S. Fastqc: A Quality Control Tool for High Throughput Sequence Data. 2010. Available online: http://www.bioinformatics.babraham.ac.uk/projects/fastqc (accessed on 1 August 2020).

21. Nurk, S.; Bankevich, A.; Antipov, D.; Gurevich, A.; Korobeynikov, A.; Lapidus, A.; Pribelsky, A.; Pyshkin, A.; Sirotkin, A.; Sirotkin, Y.; et al. Assembling genomes and mini-metagenomes from highly chimeric reads. In Annual International Conference on Research in Computational Molecular Biology; Springer: Berlin/Heidelberg, Germany, 2013; pp. 158-170.

22. Brettin, T.; Davis, J.J.; Disz, R.; Edwards, R.A.; Gerdes, S.; Olsen, G.J.; Olson, R.; Overbeek, R.; Parello, B.; Pusch, G.D.; et al. RASTtk: A modular and extensible implementation of the RAST algorithm for building custom annotation pipelines and annotating batches of genomes. Sci. Rep. 2015, 5, 8365. [CrossRef]

23. Parks, D.H.; Imelfort, M.; Skennerton, C.T.; Hugenholtz, P.; Tyson, G.W. Assessing the quality of microbial genomes recovered from isolates, single cells, and metagenomes. Genome Res. 2014, 25, 1043-1055. [CrossRef]

24. Goris, J.; Konstantinidis, K.T.; Klappenbach, J.A.; Coenye, T.; Vandamme, P.; Tiedje, J.M. DNA-DNA hybridization values and their relationship to whole-genome sequence similarities. Int. J. Syst. Evol. Microbiol. 2007, 57, 81-91. [CrossRef]

25. Richter, M.; Rosselló-Mora, R.; Glöckner, F.O.; Peplies, J. JSpeciesWS: A web server for prokaryotic species circumscription based on pairwise genome comparison. Bioinformatics 2015, 32, 929-931. [CrossRef] [PubMed]

26. Meier-Kolthoff, J.P.; Auch, A.F.; Klenk, H.P.; Göker, M. Genome sequence-based species delimitation with confidence intervals and improved distance functions. BMC Bioinform. 2013, 14, 60. [CrossRef] [PubMed]

27. Pascual, J.; Wüst, P.K.; Geppert, A.; Foesel, B.U.; Huber, K.J.; Overmann, J. Novel isolates double the number of chemotrophic species and allow the first description of higher taxa in Acidobacteria subdivision 4. Syst. Appl. Microbiol. 2015, 38, 534-544. [CrossRef] [PubMed]

28. Pascual, J.; Foesel, B.U.; Geppert, A.; Huber, K.J.; Boedeker, C.; Luckner, M.; Wanner, G.; Overmann, J. Roseisolibacter agri gen. nov., sp. nov., a novel slow-growing member of the under-represented phylum Gemmatimonadetes. Int. J. Syst. Evol. Microbiol. 2018, 68, 1028-1036. [CrossRef] [PubMed]

29. Heimbrook, M.E.; Wang, W.L.; Campbell, G. Staining bacterial flagella easily. J. Clin. Microbiol. 1989, 27, 2612-2615. [CrossRef]

30. MIDI. Sherlock Microbial Identification System Operating Manual, Version 6.1; MIDI Inc.: Newark, DE, USA, 2008.

31. Sasser, M. Identification of bacteria by gas chromatography of cellular fatty acids, MIDI Technical Note 101. USFCC Newsl. 1990, 20, 16.

32. Chun, J.; Oren, A.; Ventosa, A.; Christensen, H.; Arahal, D.R.; Da Costa, M.S.; Rooney, A.P.; Yi, H.; Xu, X.-W.; De Meyer, S.; et al. Proposed minimal standards for the use of genome data for the taxonomy of prokaryotes. Int. J. Syst. Evol. Microbiol. 2018, 68, 461-466. [CrossRef]

33. Kim, M.; Oh, H.S.; Park, S.C.; Chun, J. Towards a taxonomic coherence between average nucleotide identity and 16S rRNA gene sequence similarity for species demarcation of prokaryotes. Int. J. Syst. Evol. Microbiol. 2014, 64, 346-351. [CrossRef]

34. Richter, M.; Rosselló-Mora, R. Shifting the genomic gold standard for the prokaryotic species definition. Proc. Natl. Acad. Sci. USA 2009, 106, 19126-19131. [CrossRef]

35. Chun, J.; Rainey, F.A. Integrating genomics into the taxonomy and systematics of the Bacteria and Archaea. Int. J. Syst. Evol. Microbiol. 2014, 64, 316-324. [CrossRef] 
36. Annous, B.A.; Becker, L.A.; Bayles, D.O.; Labeda, D.P.; Wilkinson, B.J. Critical role of anteiso-C $15: 0$ fatty acid in the growth of Listeria monocytogenes at low temperatures. Appl. Environ. Microbiol. 1997, 63, 3887-3894. [CrossRef] [PubMed]

37. Zhu, K.; Ding, X.; Julotok, M.; Wilkinson, B.J. Exogenous isoleucine and fatty acid shortening ensure the high content of anteiso-C15:0 fatty acid required for low-temperature growth of Listeria monocytogenes. Appl. Environ. Microbiol. 2005, 71, 8002-8007. [CrossRef] [PubMed]

38. Kálová, S. Role of fatty acids in cold adaptation of Antarctic psychrophilic Flavobacterium spp. Syst. Appl. Microbiol. 2017, 40, 329-333. [CrossRef] [PubMed]

39. Doijad, S.; Barbuddhe, S.; Garg, S.; Poharkar, K.V.; Kalorey, D.R.; Kurkure, N.V.; Rawool, D.B.; Chakraborty, T. Biofilm-forming abilities of Listeria monocytogenes serotypes isolated from different sources. PLoS ONE 2015, 10, e0137046. [CrossRef]

40. Rahi, P.; Kurli, R.; Pansare, A.N.; Khairnar, M.; Jagtap, S.; Patel, N.B.; Dastager, S.G.; Lawson, P.A.; Shouche, Y.S. Microbacterium telephonicum sp. nov., isolated from the screen of a cellular phone. Int. J. Syst. Evol. Microbiol. 2018, 68, 1052-1058. [CrossRef]

(C) 2020 by the authors. Licensee MDPI, Basel, Switzerland. This article is an open access article distributed under the terms and conditions of the Creative Commons Attribution (CC BY) license (http://creativecommons.org/licenses/by/4.0/). 